\title{
The legacy and long afterlife of Old English poetry
}

\begin{tabular}{|c|c|}
\hline $\begin{array}{l}\text { The Germanic people who } \\
\text { inhabited England before } \\
\text { William the Conqueror became } \\
\text { ruler in } 1066 \text { spoke a language } \\
\text { known as Old English. Steeped } \\
\text { in the art of storytelling, theirs } \\
\text { was essentially an oral culture } \\
\text { and few tales were committed } \\
\text { to manuscripts that have } \\
\text { survived. Those that do are } \\
\text { testament to the rich legacy of } \\
\text { its verse. The legacy and long } \\
\text { afterlife of Old English poetry, } \\
\text { and the reception history of its } \\
\text { stories, are the subjects of new } \\
\text { research by Robert E. Bjork of } \\
\text { Arizona State University. }\end{array}$ & $\begin{array}{l}\text { or a body of literature recorded in } \\
\text { just four manuscripts, Old English } \\
\text { poetry has a legacy that belies } \\
\text { the small number of works that have } \\
\text { survived the } 1,000 \text { or more years since } \\
\text { they were first written down. } \\
\text { The most famous is the eponymous } \\
\text { epic 'Beowulf'. Others include the } \\
\text { Biblically-inspired 'Dream of the Rood' } \\
\text { and historic narratives such as 'The } \\
\text { Battle of Maldon'. A major manuscript } \\
\text { of Old English verse, the 'Exeter Book', } \\
\text { includes more than } 90 \text { riddles and some } \\
40 \text { poems, including 'The Seafarer', 'The } \\
\text { Wanderer' and 'Wulf and Eadwacer'. } \\
\text { Housed in Exeter Cathedral in the } \\
\text { United Kingdom, the 'Exeter Book' was } \\
\text { recognised in } 2016 \text { by UNESCO as one } \\
\text { of the world's principal cultural artefacts } \\
\text { by placing it on its Memory of the World } \\
\text { register. Noting the manuscript as "the } \\
\text { foundation volume of English literature", } \\
\text { the register also includes the Magna }\end{array}$ \\
\hline
\end{tabular}

\section{[Sc.]} Ian-guage $n$. TOF.

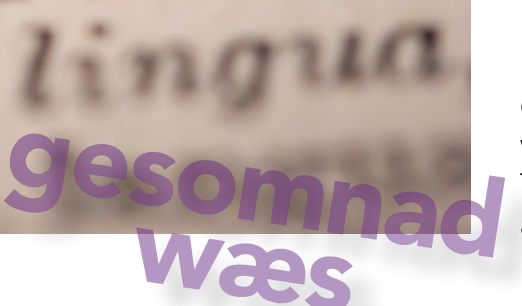
He naentr Was
Carta, Bayeux Tapestry, Book of Kells and the Diary of Anne Frank.

Small wonder then, that the afterlife fOld English poetry is long, despe he fact that for most people it is only accessible in translation from the original language. That translation process began relatively late, with the first texts in modern English being published in the 19th century. Those texts have since been translated into numerous other languages, allowing Old English poetry to migrate and, as the UNESCO listing acknowledges, achieve global significance.

As a result, not only has Old English poetry come to inspire writers and poets from J.R.R. Tolkien to Ezra Pound and W.H. Auden, 'Beowul' numerous works in different genres and languages. Meanwhile the geademic study of the texts continues apace, as Old English poetry is seen through the lens of different literary theories and world views.

RECEPTION HISTORY Arizona State University, is a respected Old English scholar and editor. One of his recent papers examines the reception history of Old English poetry.

Reception theory derives from the concept of reader response popular With literary crics since the 1970s. art's meaning and significance is not na inzeap dazum. peod cymm hym sf frumon hata cepelinsal elle fremedon. ofe foyld feepuns feeaper eatum monezí mespum meado peclit

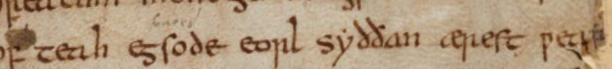
fer rceape punden he poes qropre seba peox undep polenum peojas myndism pah of phim ashpyle papa yomb fizzendya oper hron pase hypan feolde sombar syldan tprer zod cynins. deme expequa par efrequ cen ned seons in seapdum pone 5od rende folce zoproppe fypar tempe on

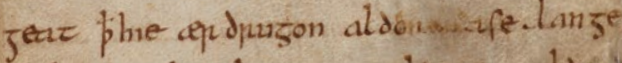
hpile hrm paci lip freas puldsief pealis

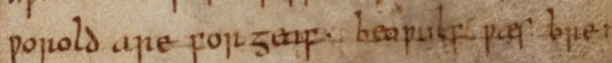

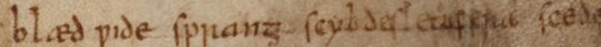

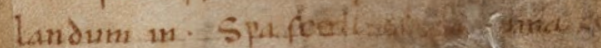

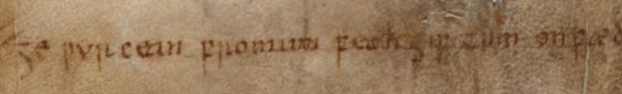

inherent in the work but rather exists in relation to its audience. The reader, viewer or listener interprets a poem, play, novel or other work of art according to his or her cultural background and

life experience. therefore the study The links that some have found between "'Bhe influence of of the many ways 'Wulf and Eadwacer' and 'The Secret vast and continuing art is understood Agent' arise from forced readings of over time and in
different cultures different cultures
as it is transmitted as it is transmitted,
re-imagined or appropriated.

'Beowulf' is the story of a fearless warrior, a prince of the Geats in mode
Sweden. Beowulf goes to Denmark to help King Hrothgar rid himself of a terrible monster, Grendel, and then, after years of peace, dies battling a dragon that threatens his own land. In a recent paper Dr Bjork traces story from the publication of its firs trans ifion the publication of its first Danish / I celandic scholar Grímur Jónsson Thorkelin, to the present day Dr Bjork explains that Thorkelin visited Britain on a "nationalistic voyage" to source documents related to Danish and Norwegian history. He found
Dr Bjork comments: both poems.

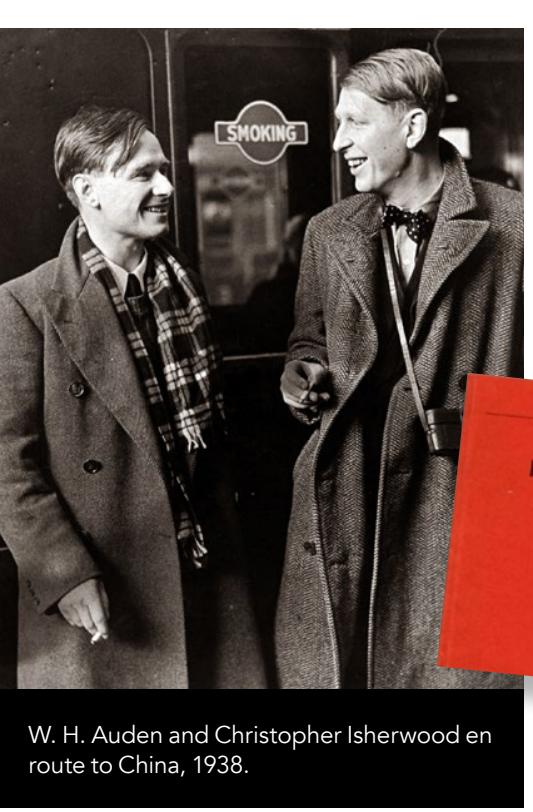

most celebrated and Other poets have imagined the tale written a poem from the dragon's point of view. For Dr Bjork, one of the most imaginative re-tellings has been by the American author Michael Crichton, whose novel 'Eaters of the Dead' was Thirteenth Warrior' starring Antonio Banderas.

Perhaps the greatest testament to the universal, psychological appeal of Beowul's good versus evil narrative is its re-Imagining in different media global generation. This includes comic works to operas and contem r rom chor rock. As Dr Bjork notes, the character of Beowulf even appears in cult fantasy television series such as the American features the voices of Anthony Hopkins, annals of the British Library. transcription and translation, 'Beowul' least 65 other languages, including Japanese, Chinese, Korean and the reception history constantly evolving."
Beowulf has stepped off the manuscript and becone acul of the mas around the globe.

\section{OCKHAM'S RAZOR}

Conversely, while some argue that a modern work of art references Old English poetry, others may see the nother recent paper Dr Bjork looks at evidence for the alleged links between the Old English lyric poem 'Wulf and Eadwacer' and the English poet W.H. Auden's poem 'The Secret Agent'

Like the other major poems in the 'Exeter Book', 'Wulf and Eadwacer' been by the lish poet Seamus has the English writer Maureen Duffy has strips, graphic novels, video games, animated film by Robert Zemeckis which 


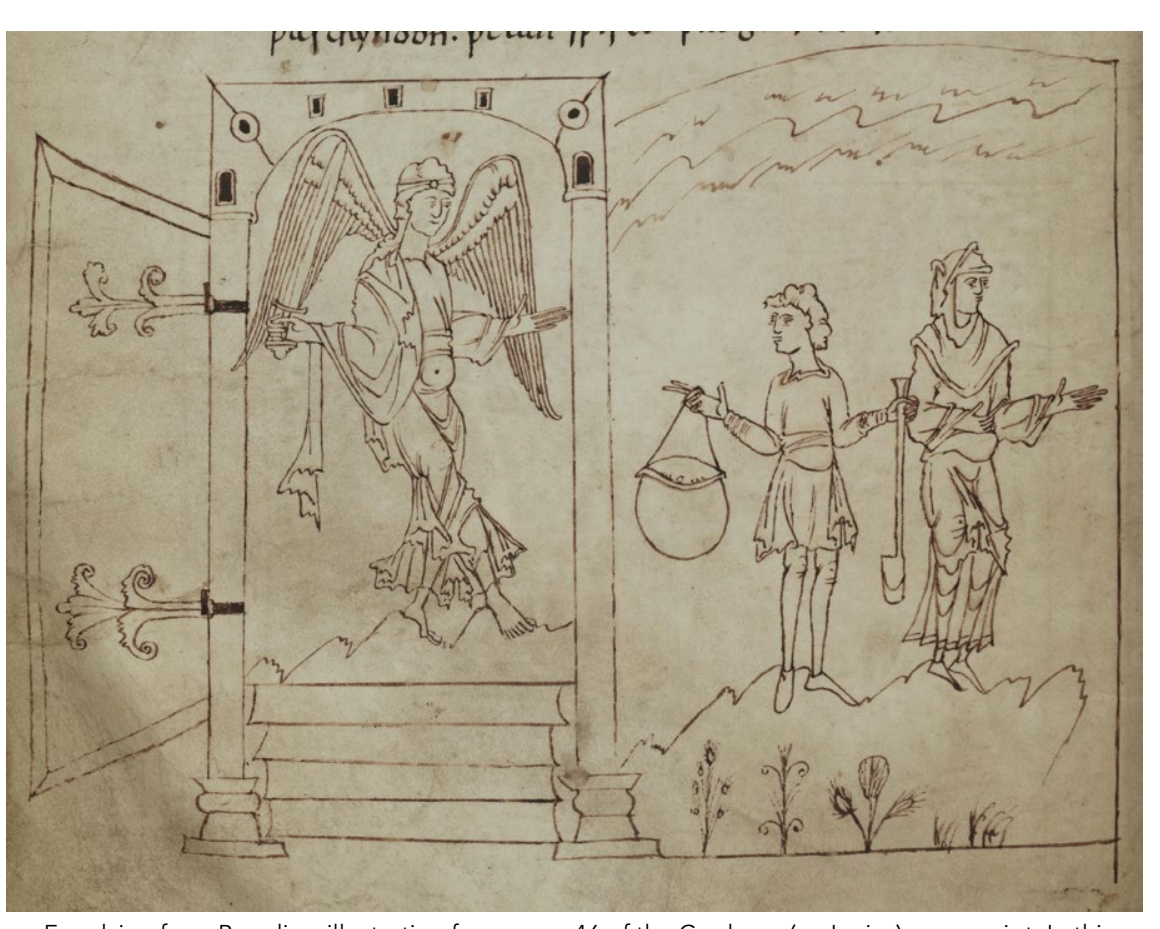

Expulsion from Paradise, illustration from page 46 of the Cæe
illustration, an angel is shown guarding the gates of Paradise.

themes of longing, loneliness and the passage of time. A monologue in whic a captive woman speaks about her unconsummated love for an outlawed lover on a neighbouring island, it ends with the line 'bæt mon eabe tosliteð pætte næfre gesomnad wæs', which translates as 'They can easily part that which was never joined together'.

In his early poem 'The Secret Agent', the modern English poet W.H. Auden writes about a highly trained spy who is caught in a trap. The agent falls for a 'bogus guide' who helps them access a site the two men needed to get into. As the ag with the lin 'Parting easily two tha were never joined.'

Named after the Anglo Saxon saint Wystan, W.H. Auden studied Old English poetry while reading English at Oxford. He was taught, among others, by J.R.R. Tolkien, author of the 'Lord of the Rings' trilogy which owes its own debt to Old English poetry. Written in 1928, the year W.H. Auden graduated, 'The Secret Agent' has been the subject of much literary debate.

The poem is thought by many to be in the sonnet tradition, not least because it comprises 14 lnes. However, Dr Bjok argues that such a reading overlooks

English sonnet traditions. For example, the Italian sonnet is structured by having two four-lined verse quatrain followed by a six-lined sestet, where the English sonnet has three four-lined verse quatrains and a final two-lined couplet. Each moves more or less from the statement of a problem to its solution. Dr Bjork explains that in Auden's poem

'Beowulf' has been translated into at least 65 other languages, including Japanese, Chinese, Korean and the Indian language Telugu. "there are just two quatrains and a sestet, loosely connected" with no resolution. patterns of Italian and English sonnets, W.H. Auden's poem is unrhymed and has a metre or rhythm that is uncharacteristic of either sonnet form.

For Dr Bjork the links that some have found between 'Wulf and Eadwacer' and 'The Secret Agent' arise from "forced readings of both poems". Recognising that 'Wulf and Eadwacer', Nike W.H. Auden's poem, is open to a range of interpretations, Dr Bjork equally rejects the views of critics who have attempted to

stories. He explains that thing to establish such links traps the reader and compels Old her to hear "resonances of the where there are none. Hower one" agree that there is a single and "absolute" (c) two poems. Anything more, he explains, is fabrication. Applying Ockham's razorthe principle attributed to the medieval scholar William of Ockham, who argued hat when faced with various explanations for a phenomenon, the simplest is usually the correct one-he points to observation that some of Auden's juvenilia are hurried compilations of Whith $\mathrm{T}$ 'Thes. This seems to be the case in it of a single line from Old English.

NEW WORKS

Old English poetry already has an extend beyond the present day. This thanks not least to new works such as Dr Bjork's own translations of the major poems and his novella 'Freya and Wulf: A 9th-Century Love Story of Violence and Redemption'. Inspired by 'Wulf and Eadwacer', the novella also references 'Beowulf', and other Old English and Old Norse texts. It's proof indeed that Old English poetry continues to provide a ric seam for other storytellers, new and old.

\section{Behind the Research} Robert E. Bjork

: robert.bjork@asu.edu T: +1 (480) 231-9018 T: +1 (480) 965-4659

Research Objectives

Robert E. Bjork's primary research areas are Old English poetry, modern Swedish literature, and biomedical writing.

\section{Detail}

\section{Address}

of English, Arizona State University

Tempe, AZ 85287-1401

Bio

Robert E. Bjork is Foundation Professor of English at Arizona State University and a Fellow of the Medieval Academy of America. He is currently editing a special issue of the online Legacy'

The ASU Foundation

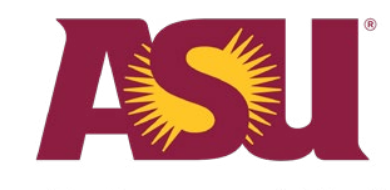

Arizona State University

\section{References}

Bjork, R.E. (2020). The Reception History of Beowulf. SELIM. Journal of the Spanish Society for Medieval English Language and Literature 25, 1-19.

Bjork, R.E. (forthcoming). W.H. Auden's 'The Secret Agent,' the Old English 'Wulf and Eadwacer,' and Ockham's Razor. ANO: A Quarterly Journal of Short Articles, Notes, and Reviews. Available online: https://www.tandfonline.com/doiffull/10.108

Bjork, R.E. (2016). Freya and Wulf: A 9th Century Love Story of Violence and Redemption. CreateSpace.com.

(Editor and translator) Bjork, R.E. (2015). Old English Shorter Poems Volume ll: Wisdom and Lyric. The Dumbaton Oaks Medieval Library, Vol. 32.

\section{Personal Response}

What is it about Old English poetry, particularly 'Beowulf', that makes it appeal to people in so many

II The poetry is gripping, complex, enigmatic, and suffused with beauty and wisdom and sometimes terror. 'Beowulf' teaches us about life and its vicissitudes. Reading it, we come to see how our struggles against negative forces from within and without ennoble us in the end.

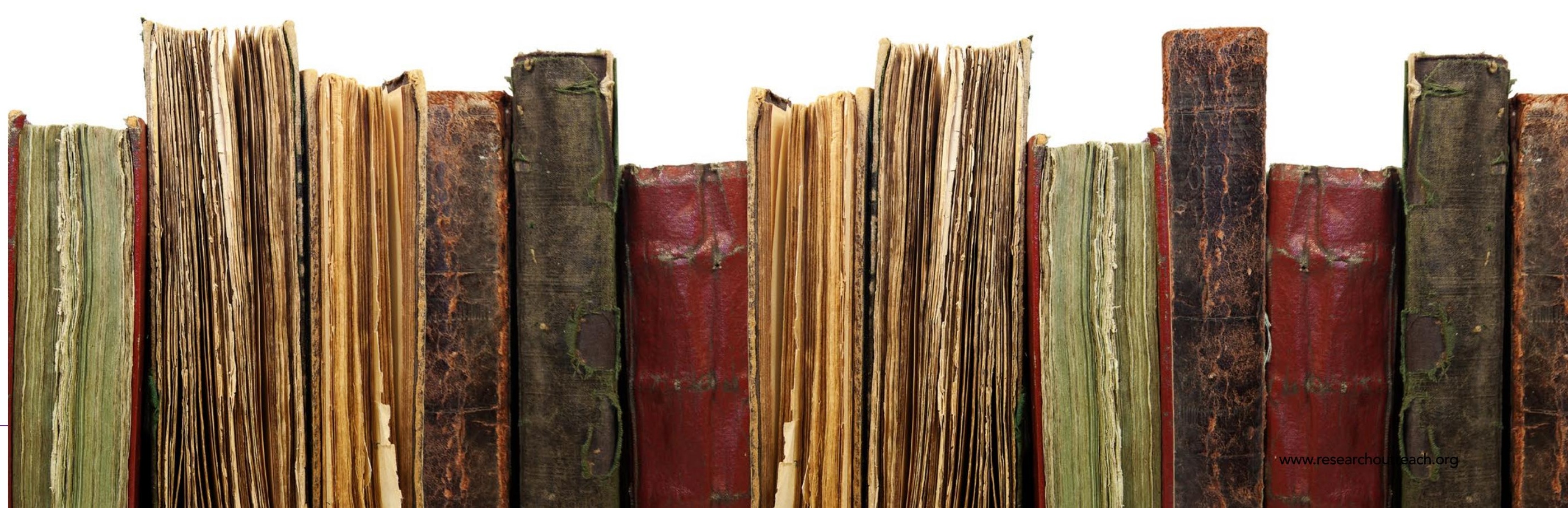

